\title{
Research on the Present Status and Prospects of China's Biomass Energy Power Generation
}

\author{
Ling-wen-ying $\mathrm{Li}^{1}$ \\ Department of Economic and Management , North China Electric Power University, Beijing, 102206, \\ China
}

Keywords: biomass, biomass energy power generation, renewable Energy.

\begin{abstract}
China depends heavily on coal to meet its electricity and economic development needs for a long time and it has surpassed America and became the biggest greenhouse gases emission country in the world. The appearance of biomass energy power generation has been easing the tension of domestic energy and environmental issues, which is significant.The paper based on the connotation and characteristics of biomass energy power generation, described the biomass energy power generation technology in China, discussed the problems wherein and finally talked about the prospects for the development of biomass energy power generation in China.
\end{abstract}

\section{Introduction}

Energy is the material basis of human activity and the development of human society is inseparable from the emergence of high-quality energy and the use of advanced energy technologies.Energy shortage,as well as deterioration of the ecological environment caused by energy consumption,has prompted the world looking for clean, efficient and new alternative energy sources.Biomass refers to a variety of organisms produced by photosynthesis.Biomass energy is an form of solar energy based on biomass and stored in it as chemical energy, which is inexhaustible [1].

Biomass energy power generation originated in the 1970s.Denmark began to actively develop clean and renewable energy and vigorously promote biomass energy power generation because of the oil crisis.Many European and American countries began to follow the implementation of Biomass energy power generation in Denmark since 1990 [2].Currently, biomass energy power generation technology on behalf of efficient direct-fired power generation has been more mature in foreign countries.

With the rapid development of China's economy, its energy consumption is growing, too.China is a large agricultural country with rich biomass resources and produce about 700 million tons of straw annually.Among them, about 400 million tons can be used, which means huge potential for development.Biomass power can replace a lot of coal, oil, natural gas and other fuels in power generation and effectively reduce environmental pollution while protecting national resources.It can be said that biomass energy power generation is a bright star on the new domestic energy issues.

\section{Connotation and characteristics of biomass energy power generation}

Energy problem is one of the severe challenges humanity is facing in the 21st century.Fossil fuels is nonrenewable and its reserves are limited.After combustion, large amounts of carbon dioxide, nitrogen, sulfur oxides and other harmful gases are released, which seriously polluted the environment and cause the greenhouse effect, global warming, species diversity decrease, desertification and many other ecological problems.Thus, in 2010 to 2020, global energy usage patterns may change rapidly and renewable energy will replace fossil fuels.

Biomass energy is an emerging energy that make energy production with organic waste in agriculture and forestry and energy plants in marginal land as the main raw material.Biomass energy power generation mainly use wastes in agriculture, forestry, industry and even municipal waste as a raw material [3] to convert their own energy into the form to drive engine and then generate electricity according to general technology.Finally the electricity will be directly provide 
to the users or accessed to the grid for use.Recent years, domestic energy situation and electricity supply has become increasingly nervous, so biomass power increasingly highlighted its importance in the case.

Biomass energy power generation has the following features :

i) Cleaner: Biomass energy power generation has low pollution because biomass has few sulfur content and few pollutant emissions while the power generation process.Carbon dioxide emissions to atmospheric is near zero when biomass is as fuel and this can effectively reduce the greenhouse effect.So the biomass fuels are clean energy.

ii) Sustainable: As a sustainable energy, biomass is clean and renewable.It can change from solar energy into chemical energy fixed and stored in organism through photosynthesis uninterruptedly and directly or indirectly.Therefore, power generation using biomass energy is also non-disposable and it has the characteristic of sustainability.

iii) Low density: Biomass energy is more scattered in distribution and not easy to transport, which cause the biomass energy power generation has the characteristic of low density.

\section{Applications of China's biomass energy power generation}

\section{Development process of China's biomass energy power generation technology}

As we all know, China is a traditional agricultural country with abundant biomass resources.High energy crops such as sweet sorghum, cassava, jatropha, switchgrass, Miscanthus crop, have been paid more and more attention in recent years.At the same time, relevant research institutions and companies have continued to participate in the research and development of biomass energy, providing a reliable guarantee for biomass energy industry.

China biomass power generation technology research began in the 1990s, in which rice husk gasification power plant is most representative. $1 \mathrm{MW}$ rice husk gasification power generation demonstration project completed and put into operation in 1998 and it laid the foundation for China's biomass energy power generation technology.In 2006, China's total installed capacity of biomass power generation was about $2000 \mathrm{MW}$, of which sugar cane bagasse power generation accounted for about 1700 MW.From December, 2006, when China's first biomass direct combustion power generation project, Guoneng Shanxian Biomass Power Plant, officially put into operation, to August, 2008, China has approved over 130 agriculture and forestry biomass energy power generation projects cumulatively and the total installed capacity is about $3000 \mathrm{MW}$ and 25 biomass direct combustion power generation projects began to produce electricity and send to the grid.

Large state-owned enterprise including the State Grid Corporation and five power generation groups, like many private companies and foreign-funded companies, have invested in China to participate in the construction and operation of biomass power industry. As the following picture shows, biomass energy power generation capacity in China is constantly rising.The Twelfth Five-year Plan for Biomass Development puts forward that annual use of biomass will exceed 50 million tons of standard coal by 2015. Wherein, biomass energy installed power generation capacity is 13 million kilowatts and annual generating is about 78 billion kwh. 


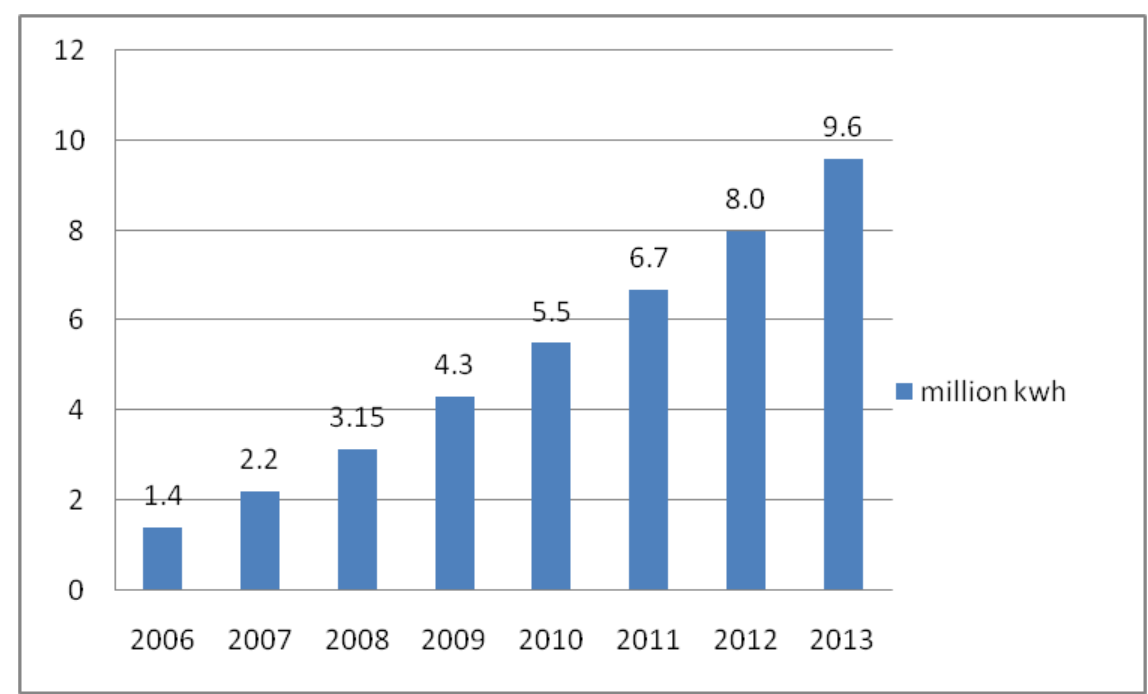

Fig.1: Annual biomass energy power generation capacity in China

\section{China's policy of development of biomass energy power generation}

Considering the advantages and benefits brought by biomass energy power generation, China takes developing biomass energy as one of the effective energy-saving measures and treats the biomass energy power generation as one of the main components of biological exploitation.

These years, China has promulgated a series of laws, regulations and policy initiatives, built biomass legal system including biomass energy management system, economic incentive system, the total target system and technical standards system and gradually formed a good macroeconomic policy environment.

In 2006, China promulgated the Renewable Energy Law, and implemented a biomass power tariff concessions and other relevant policy, which promoted the rapid development of biomass energy power generation, especially straw power generation.From 2007 to 2013, China's relevant departments continued to adopt a series of policy measures to promote the development of biomass power generation industry, consisting of Notice About Biomass Power Generation Project Management, The Twelfth Five-year Plan for Biomass Development, The Twelfth Five-year Plan for Renewable Energy and The Twelfth Five-year Plan for Energy Development. China is giving a series of concessions in the relevant sectoral policies and its biomass power generation will enter the phase of rapid development with the gradual improvement of industrial policy.

\section{The basic problems of China's biomass energy power generation}

Overall, China's biomass energy power generation applications is just beginning, with lower degree of industrialization and commercialization, weak market competitiveness, lacking of sustained development capacity, gap in terms of raw material collection, combustion equipment manufacturing, gas purification, etc.Besides, projects are mostly in the demonstration phase.Here are the problems:

i) High construction and operating costs: According to the actual operation statistics of biomass power plants abroad and Chinese authorities calculations, biomass energy power generation costs 1.5 to 2.0 times the cost of coal-fired power [4].First, biomass energy power generation has a large initial investment and the current average cost per $\mathrm{kW}$ is 1 million or more.Second, it has higher fuel costs.Because of low density and scattered distribution and resulting transportation difficult, transportation costs, processing costs and other loss take a larger proportion in fuel costs.Third, lower thermal efficiency, complex feeding system, high operating costs and high maintenance costs jointly contributed to the high cost of biomass power plants.Finally, biomass power plants need professional run and support staff, which cause higher labor costs.

ii) Lack of mature core technology and equipment: China's biomass energy power generation is mainly limited by technology and equipment system.For now, the vast majority of technology and 
equipment for fuel delivery system and boilers for biomass incineration power rely heavily on imports.There is no mature domestic products manufacturer.Lacking of research strength, no supporting from plant equipment and the reality that related professional talent gap can not meet the market demand jointly become the bottleneck of China's biomass energy power development.

iii) Demonstration projects are not fully functional: Implementation of biomass energy power generation demonstration projects can make from the point to surface and play a typical role model.However, due to various reasons, such as funding, technology and management, currently, already existing demonstration projects in China did not fully play its role well, affecting the enthusiasm of investors.At the same time, for some of the problems in the demonstration project, neither has the government taken effective measures and incentives to guide the healthy development of biomass energy power generation.

\section{Prospect of China's biomass energy power generation}

From the following picture, we can clearly find that China has abundant and variety biomass resources.China's biomass resources quantity is about 700 million ton of coal and expected to reach 900 million to 1 billion ton of coal with the Grain and planting firewood [5].Therefore, the use of biomass energy power generation will be an important part of China's energy structure adjustment.

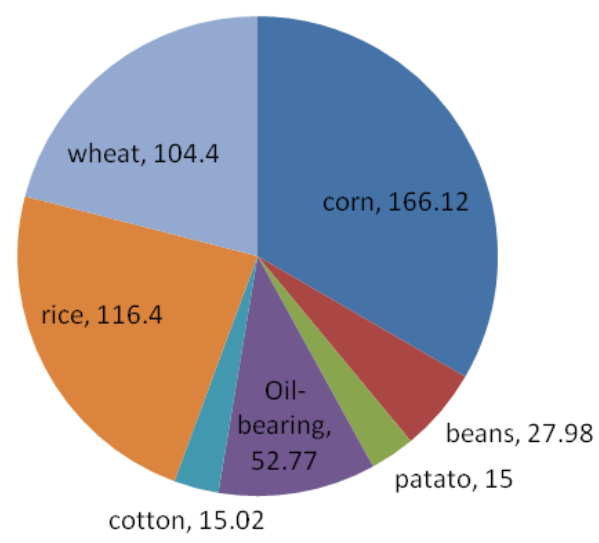

Fig.2: The main crop straw generation capacity(unit: million ton)

Currently, the Chinese government and relevant departments has attached great importance to the use of biomass energy, taken the research and application of biomass utilization technologies as a key scientific and technological projects continuously in series of The Twelfth Five-year Plan, carried out research and development of biomass utilization technologies and made a number of outstanding achievements in terms of large biogas, gasification and gasification power generation and biomass liquid fuels.

With the adjustment of industrial structure, the national policies on biomass energy industry will continue to increase and strengthen to call for energy conservation and sustainable development of society.Existing biomass power projects, referential development experience of developed countries and national renewable energy policy orientation will promote biomass energy industry into the peak period of rapid development.We can believe that China's biomass power industry will have a breakthrough and broad prospects for development, which will make an important contribution to solve the energy shortage and reduce global environmental pollution.

\section{References}

[1] Himmel M E , Ding S Y, Johnson D K, et al, Biomass recalcitrance: En-gineering plants and enzymes for biofuels production.Science,315 (5813),pp.804-807,2007.

[2] Liu-Qin Chen, Where China biomass power go.Review of Economic Research, 51,pp.37-44,2013. 
[3] Dornburg V, Termeer G, Faaij A P C, Economic and greenhouse gas emission analysis of bioenergy production using multi-product crops-case studies for the Netherlands and Poland.Biomass \& Bioenergy, 28 (5),pp.454 - 474,2005.

[4] Gross R , Leach M , Bauen A, Progress in renewable energy.Environment International, 29 (1),pp.105 - 122,2003.

[5] Ying-Chao Huang, Wen-Zhe Li, Bo Zhang, Current situation and prospect of biomass power generation technology.Journal of Northeast Agricultural University, 38 (2),pp.270-274,2007. 